\title{
The legality of Australia's plain packaging legislation: Cuban cigars and geographical indication rights under the TRIPS Agreement
}

\author{
SOPHIE TAYLOR
}

\section{Abstract}

Australia's 'plain packaging' legislation mandates the removal of all promotional aspects of tobacco packaging, leaving only the brand name displayed in a standard font, size, colour and location on tobacco products sold in Australia. In response to this measure, Ukraine, Honduras, Cuba, Indonesia and the Dominican Republic have engaged in dispute consultations at the World Trade Organization (WTO), claiming the Act violated their rights under several WTO Agreements, including the TradeRelated Aspects of Intellectual Property (TRIPS) Agreement. This essay will analyse Cuba's claims under Article 22 and 24 of this agreement regarding the plain packaging of Cuban cigars and their geographical indication rights in Australia. This essay will argue that given Australia's strong legal framework to protect geographical indications, and the increasingly harmonious approach by the WTO to support the World Health Organization's public health policies, Australia is likely to successfully defend Cuba's claim.

\section{An introduction to Australia's plain packaging legislation}

It is estimated that tobacco usage will be the direct cause of death of one billion people this century. ${ }^{1}$ Tobacco smoking remains one of the leading causes of preventable death and disease in Australia, accounting for 15,000 deaths per annum and amounting to social costs of over $\$ 31.5$ billion. $^{2}$ Governments have two legitimate interests in the regulation of tobacco products: first, due to their

1 World Health Organization, Tobacco Fact Sheet Number 339 (2014) www.who.int/mediacentre/factsheets/ fs339/en/.

2 David J. Collins and Helen M. Lapsley (2008) Department of Health and Ageing (Cth), The Costs of Tobacco, Alcohol and Illicit Drug Use to Australian Society 65. 
obligations to contribute to the social development of their respective nations, the health of their citizens, and their national budget; and, second, as the representatives of consumers. At an international level, many recently introduced tobacco regulations have been codified within the World Health Organization (WHO) Framework Convention on Tobacco Control (FCTC), a multilateral treaty aimed at protecting populations from tobacco consumption and exposure to tobacco smoke. ${ }^{3}$ Among the regulatory measures recommended by the FCTC is Article 11 which deals with 'Packaging and labelling of tobacco products'. ${ }^{4}$ The Guidelines for Implementation for Article 11 recommend that '[p]arties should consider adopting measures to restrict or prohibit the use of logos, colours, brand images or promotional information on packaging other than brand names and product names displayed in a standard colour and font style ("plain packaging")'.

The Australian Commonwealth Government implemented the world's first tobacco plain packaging scheme under the Tobacco Plain Packaging Regulations 2011 applying to cigarettes, on 7 November 2011.6 The Tobacco Plain Packaging Amendment Regulations 2012, made on 8 March 2012, amended the 2011 regulations to incorporate additional plain packaging specifications for noncigarette tobacco products. $^{7}$ These regulations were enforced under the Tobacco Plain Packaging Act (2011) (Cth) ('Plain Packaging Act') in July 2012. ${ }^{8}$

The objectives of this legislation include improving public health by: reducing the appeal of tobacco products to consumers; increasing the effectiveness of public health warnings on the retail packaging of tobacco products; reducing the ability of the retail packaging of tobacco products to mislead consumers about the harmful effects of smoking; and to give effect to obligations under the FCTC. ${ }^{9}$ This Act requires:

the removal of colours, brand imagery, corporate logos and trademarks, permitting manufacturers to print only the brand name in a mandated size, font and place, in addition to the required health warnings and other legally mandated product information such as toxic constituents, tax-paid seals or package contents. ${ }^{10}$

3 World Health Organization Framework Convention on Tobacco Control, opened for signature 16 June 2003, 2302 UNTS 166 (entered into force 27 February 2005).

4 Ibid art 11.

5 World Health Organization, Guidelines for implementation of Article 11 of the WHO Framework Convention on Tobacco Control (Packaging and labelling of tobacco products), Article 46. www.who.int/fctc/guidelines/article_11. pdf?ua $=1$.

6 Tobacco Plain Packaging Regulations 2011 (Cth).

7 Tobacco Plain Packaging Amendment Regulations 2012 (Cth).

8 Tobacco Plain Packaging Act 2011 (Cth).

9 Ibid s 3.

10 Becky Freeman, Simon Chapman and Matthew Rimmer, 'The Case for Plain Packaging of Tobacco Products' (2011) 103 Addiction 580-581. 
Ukraine, Honduras, Cuba, Indonesia, and the Dominican Republic have requested dispute consultations at the World Trade Organization (WTO) with Australia in relation to the Plain Packaging Act. ${ }^{11}$ These five complainants assert that Australia's plain packaging laws breach the WTO's General Agreement on Tariffs and Trade (GATT), Agreement on Technical Barriers to Trade (TBT Agreement) and Agreement on Trade-Related Aspects of Intellectual Property Rights (TRIPS Agreement) in that they are discriminatory, more trade restrictive than necessary, unjustifiably infringe upon tobacco company's trade mark rights, and cause unfair competition and diminish protection regarding geographical indications (GIs). These disputes against Australia are particularly important as they will determine the compatibility of the Plain Packaging Act with Australia's international obligations and the interaction of these trade agreements with nontrade agreements such as the FCTC. The disputes have the potential to become authorities regarding the balance of public health policy and international trade. Furthermore, it has been speculated that if Australia is successful in defending plain packaging, it may cause a domino effect on tobacco regulation and lead to the introduction of plain packaging around the world. ${ }^{12}$

One of the key legal objections to the Plain Packaging Act is that plain packaging of tobacco violates minimum intellectual property obligations mandated by the TRIPS Agreement. Specifically, Cuba is alleging the plain packaging of cigars has caused deprivation of intellectual property rights in regards to their GIs under Articles 22 and 24 of the TRIPS Agreement. These GI articles have not received significant academic attention in relation to Australia's plain packaging disputes. Critics suggest this is because the complainants have included these 'geographical indication clauses' as a matter of form to deflect suspicions that they are acting as puppets of the global cigarette companies. ${ }^{13}$ It has been reported that Philip Morris Tobacco is providing support to Dominican Republic, and that British American Tobacco is providing support to Ukraine and Honduras. ${ }^{14}$

Australia bears the burden of proving that the Plain Packaging Act conforms to these international obligations, as the WTO Member imposing the measure. ${ }^{15}$ In assessing Australia's alleged contravention of its obligations under the TRIPS

11 Parliamentary Library, Australia's WTO Plain cigarette packaging case: an update (8 July 2014) Parliament of Australia, www.aph.gov.au/About_Parliament/Parliamentary_Departments/Parliamentary_Library/FlagPost/ 2014/July/WTO_plain_cigarette_packaging_case.

12 Andrew Mitchell, 'Australia's Move to the Plain Packaging of Cigarettes and its WTO Compatibility' (2010) 5 Asian Journal of WTO E International Health Law and Policy, 409, 411.

13 Armfield Intellectual Property Management, The question of whether Australia has contravened its obligations under the TRIPS Agreement by enacting the Tobacco Plain Packaging Act 2011 (Cth) is much clearer than many commentators have suggested (1 March 2013), static.squarespace.com/static/50c31438e 4b013f4c08abdcb/t/5296e 04de4b08ec721545ab5/1385619533649/Tobacco\%20Plain\%20Packaging.pdf.

14 Andrew Martin, 'Philip Morris leads plain packs battle in global trade arena', Bloomberg (online), 22 August 2013, www.bloomberg.com/news/2013-08-22/philip-morris-leads-plain-packs-battle-in-global-trade-arena.html. 15 Andrew Mitchell and Tania Voon, Submission No 618 to House Committee on Health and Ageing, Australian Inquiry into Tobacco Plain Packaging, 21 July 2011 at 49. 
Agreement, this essay will analyse the legal rights afforded to WTO members regarding GIs under the TRIPS Agreement, and examine these rights in the context of Cuban cigars with respect to Australia's domestic laws and international obligations. It will conclude that GIs are adequately protected from unfair competition in Australia and that this protection has not diminished since 1 January 1995. Based on this analysis, in addition to considering public health policy and the harmonisation of the WTO and WHO, it will conclude that Australia will likely succeed at defending Cuba's GI claims.

\section{The geographical indication rights of Cuban cigars}

\section{What are Gls?}

A geographical indication differs from a trade mark in the sense that a trade mark identifies the undertaking offering the product or service on the market, whereas a GI indicates the particular geographical place where the product is produced. ${ }^{16}$ Well-known examples of GIs include 'Champagne' from the Champagne region in France, or 'Darjeeling' for tea from the Darjeeling district in West Bengal, India. GIs are defined in Article 22.1 of the TRIPS Agreement as 'marks which identify a good as originating in the territory of a Member, or a region or locality in that territory, where a given quality, reputation or other characteristic of the good is essentially attributable to its geographical origin.. ${ }^{17}$

Prior to the Uruguay Round negotiations, two categories existed to protect source indications with geographical significance: appellations of origin and indications of source. Appellations of origin signify both the geographical origin of a good and the resultant features of that product due to its geographical source. Indications of source simply state the location in which the product was made. The TRIPS Agreement created a single category for these two indications. ${ }^{18}$ These two categories were protected by three international agreements prior to TRIPS: the Paris Convention for the Protection of Individual Property (Paris Convention); ${ }^{19}$ the Madrid Agreement for the Repression of False or Deceptive Indications of Source (Madrid Agreement); ${ }^{20}$ and the Lisbon Agreement for the Protection of

16 Peter van den Bossche, The Law and Policy of the World Trade Organization (Cambridge Press, 3rd ed, 2012) 989.

17 Agreement on Trade-Related Aspects of Intellectual Property Rights (TRIPS Agreement), opened for signature 15 April 1994, 869 UNTS 299 (entered into force 1 January 1995) art 22.1.

18 Ibid art 22.1.

19 Paris Convention for the Protection of Industrial Property (Paris Convention), opened for signature 14 July 1967, 828 UNTS 305 (entered into force 26 April 1970).

20 Madrid Agreement for the Repression of False or Deceptive Indications of Source (Madrid Agreement), opened for signature 14 April 1891, as revised at Stockholm in 1967, 828 UNTS 389. 
Appellations of Origin and Their International Registration (Lisbon Agreement). ${ }^{21}$ These agreements lacked high levels of ratification and substantial enforcement mechanisms. The Uruguay Round negotiations therefore provided an opportunity to include GIs in an international agreement with an enforcement mechanism to protect them throughout a large part of the world.

These negotiations divided Members, with the United States in particular resisting the introduction of GIs in the TRIPS Agreement, taking a strongly proprotectionist, pro-property view. ${ }^{22}$ The European Community, as the European Union was known at the time, pushed for the inclusion of Articles 22, 23 and 24 in the TRIPS Agreement to protect their producers of wine and agricultural products. ${ }^{23}$ Section 3 of Part II of the TRIPS Agreement therefore represents a delicate balance of different members' interests in GIs in the Uruguay Round negotiations as documented in the travaux préparatoires.

Another concern in the preparatory documents, and one that is of continuing relevance, is the diversity of national systems for the protection of GIs where there is a considerably lower level of harmonisation than in the area of trade marks. ${ }^{24}$ Since TRIPS does not stipulate a specific mechanism to protect GIs, various approaches to GI protection have evolved in different regions. These often include variations of legislation, common law, and administrative acts. In many countries, GIs are recognised as a sui generis type of industrial property, establishing an exclusive GI system of protection. The EU Council Regulation 510/2006 is a system of GI registration and protection that embodies the sui generis philosophy of GI protection. ${ }^{25}$ Some other legal systems, including Australia, address GIs as a subcategory of trade marks. ${ }^{26}$ In these systems, GIs are registered in the same way a trade marks are, and courts tend to apply trade mark principles when deciding GI cases. ${ }^{27}$ While each approach involves differences in the condition and scope of protection offered, in every system a GI right enables those who possess the indication to prevent its use by a third party whose product does not conform to the GI standards. ${ }^{28}$

21 Lisbon Agreement for the Protection of Appellations of Origin and their International Registration (Lisbon Agreement), opened for signature 31 October 1958, 923 UNTS 205 (entered into force 25 September 1966).

22 Communication from the United States - Trade Problems Encountered in Connection with Intellectual Property Rights, TRIPS Doc MTN.GNG/NG11/W/70 (11 May 1990) 9.

23 Communication from the European Communities - Trade Problems Encountered in Connection with Intellectual Property Rights, TRIPS Doc MTN.GNG/NG11/W/26 (7 July 1988) 9.

24 Chairman's Report - Trade Problems Encountered in Connection with Intellectual Property Rights, TRIPS Doc MTN.GNG/NG11/W/76 (23 July 1990) 24.

25 Erik Ibele, 'The Nature and Function of Geographical Indications in Law' (2009) 10 The Estey Centre Journal of International Law and Trade Policy 36, 39.

26 Ibid.

27 Ibid

28 World Intellectual Property Organization (WIPO), Geographical Indications (21 June 2012) www.wipo.int/ geo_indications/en/\#services. 


\section{Are Cuban cigars Gls?}

Cuban cigar sales are exclusively handled by 'Habanos', a 50/50 joint venture between the Cuban state tobacco company and Altadis, a unit of Imperial Tobacco. ${ }^{29} \mathrm{Cuba}$ has a long-established claim that Cuban cigars are protected as various GIs due to the uniqueness of the soil characteristics and the climate; the varieties of Cuban black tobacco; and the distinctive human knowledge in Cuba relating to tobacco farming and cigar production. ${ }^{30}$

During the early 1900s, Cuban Government authorities became aware of the geographical significance of Cuban cigars and the dangers of their GI's misuse. ${ }^{31}$ Cuba began to take measures to prevent misuse of their GI, including labelling Cuban cigar boxes 'Hecho en Cuba' (made in Cuba); the creation of the National Warranty Seal of Origin; the creation of the National Commission of Advertising and the Defense of the Habano Cigars; and registering brands of Cuban cigars as appellations of origin under the Lisbon Agreement. ${ }^{32}$ Cuba ratified the Lisbon Agreement on 17 September 1963,,$^{33}$ and currently has 18 registered appellations of origin on the Lisbon Register: Cuba, Habanos, Habana, Habaneros, Partido, Tumbadero, Remedios, Hoya de Manicaragua, Vuelta Arriba, Vuelta Abajo, Cabanas, San Luis, El Corojo, San Juan y Martinez, Hoyo de Monterrey, San Vicente, Las Martinas, and Pinar del Rio. ${ }^{34}$ Registering these appellations of origin under the Lisbon Agreement extends their protection to countries other than Cuba, by implying respect and recognition for the registered appellations of origin. However, Australia is not a signatory to the Lisbon Agreement and therefore protection is not guaranteed in Australia.

As noted earlier, domestic protection of GIs varies and thus the level of protection for Cuban cigars differs worldwide. The sole Cuban GI protection system is Decree No. 228 of 2002 - Geographical Indications. ${ }^{35}$ The Cuban legislation allows registry of GIs to the Denominations of Origin Registry. Cuban cigars are a protected GI under this domestic system.

29 Adargelio Garrido de la Grana, 'The Experience of Cuban Cigar Trademarks and Geographical Indications' (Speech delivered at the WIPO International Symposium on Geographical Indications, Beijing, 27 June 2007).

30 Ibid.

31 Ibid.

32 Ibid.

33 WIPO, Contracting Parties to the Lisbon Agreement (30 July 2013) World Intellectual Property Organization, www.wipo.int/treaties/en/ShowResults.jsp?lang=en\&treaty_id=10.

34 WIPO, Lisbon Express Database (17 September 2014) World Intellectual Property Organization, www.wipo. int/ipd1/en/search/lisbon/search-struct.jsp.

35 Decreto-Ley $N^{\circ} 228$ de las Indicaciones Geográficas 2002 (Cuba). 


\section{Australia's obligations regarding Gls}

Despite not being a party to the Lisbon Agreement, Australia has certain obligations in regards to intellectual property rights under both the Paris Convention and under the TRIPS Agreement. As the Uruguay Round negotiations concluded in 1994, all WTO members agreed on basic standards for GI protection. ${ }^{36}$ These oblige each member to:

i. prevent misleading statements as to the origin of the good (to which the GI is affixed) or prevent confusion to consumers under Article 22.2(a); ${ }^{37}$

ii. provide a means for interested parties to prevent unfair competition under Article 22.2(b); ${ }^{38}$ and

iii. not diminish the protection for GIs that existed in Australia prior to entering the TRIPS Agreement under Article 24.3. ${ }^{39}$

Cuba claims that plain packaging is inconsistent with Australia's obligations under Article 22.2(b), because Australia does not provide effective protection against acts of unfair competition with respect to Cuban GIs; and under Article 24, because Australia is diminishing the level of protection afforded to Cuban GIs as compared with the level of protection that existed in Australia prior to 1 January 1995.

\section{Article 22 and its implementation in Australia}

\section{Obligations under TRIPS Article 22}

The TRIPS Agreement creates positive obligations under Article 22 to afford protection according to certain minimum standards, in addition to the prohibitions against discrimination. ${ }^{40}$ The GI protection afforded by Article 22 is therefore similar to the trade mark protection afforded by Article 16, in that the member's obligation in relation to Article 22 is to prevent the use of GIs by those not entitled to their use ${ }^{41}$ creating a negative right to address the actions of third parties in misleading and unfair competition. ${ }^{42}$

Looking to the travaux préparatoires of the TRIPS Agreement it is clear that the inclusion of Article 22.2(b) was due to the inadequate protection of GIs from misuse due to the lack of ratification of the Madrid and the Lisbon Agreements,

36 Chairman's Report - Trade Problems Encountered in Connection with Intellectual Property Rights, TRIPS Doc MTN.GNG/NG11/W/76 (23 July 1990) 24.

37 TRIPS Agreement above n 18 art 22.2(a).

38 TRIPS Agreement above n 18 art 22.2(b)

39 TRIPS Agreement above n 18 art 23.4.

40 Panel Report, EC - Trademarks and Geographical Indications (Australia), WTO Doc WT/DS174/R (15 March 2005) [7.745].

41 Mark Davidson, 'Plain Packaging of Tobacco Products: The new Australian laws and the legal challenges to them' (2013) 9 Anuario Andino de Derechos Intelectuales (Andino Intellectual Rights Yearbook) 195, 204.

42 Ibid 206. 
and the lack of enforcement mechanisms under the Paris Convention. ${ }^{43}$ During the Uruguay Round negotiations, members were conflicted as to what the definition of 'unfair competition' under the TRIPS Agreement should include. Submissions from the European Community strongly recommended a particularly broad interpretation of the term, and looked to the Paris Convention's non-exhaustive list of acts of unfair competition. ${ }^{44}$ This approach was adopted by the Secretariat in the final meetings of the Uruguay Rounds ${ }^{45}$ and, therefore, in the final TRIPS Agreement the Article 22.2(b) refers to Article 10bis of the Paris Convention to define acts of unfair competition. ${ }^{46}$

Article 10bis of the Paris Convention provides a non-exhaustive list of acts of competition contrary to honest practices in industrial or commercial matters that constitute an act of unfair competition, including:

a. all acts of such a nature as to create confusion by any means whatever the establishment, the goods, or the industrial or commercial activities, of a competitor;

b. false allegations in the course of trade of such a nature as to discredit the establishment, the goods, or the industrial or commercial activities, of a competitor; and

c. indications or allegations the use of which in the course of trade is liable to mislead the public as to the nature, the manufacturing process, the characteristics, the sustainability for their purposes, or the quality, of the goods. ${ }^{47}$

The burden lies on the owner of the protected GI to prove the use of an indication by a third party constitutes an act of unfair competition. ${ }^{48}$ The TRIPS Agreement does not specify the legal means to protect GIs from these acts of unfair competition; it is at the discretion of each WTO member to determine the most appropriate method. In EC-Trademarks and Geographical Indications (Australia), the panel made an important distinction: that a member is not obliged to ensure that this particular regulation implements Article 22.2 where it has other measures

43 Communication from the Secretariat - Trade Problems Encountered in Connection with Intellectual Property Rights, TRIPS Doc MTN.GNG/NG11/W/12 (11 August 1987) 2.1(a).

44 Communication from the EC-Trade Problems Encountered in Connection with Intellectual Property Rights, TRIPS Doc MTN.GNG/NG11/W/68 (29 March 1990).

45 Communication from the Secretariat - Trade Problems Encountered in Connection with Intellectual Property Rights, TRIPS Doc MTN.GNG/NG11/16 (4 December 1989) 13.

46 TRIPS Agreement above n 18 art 22.2(b).

47 Paris Convention above $\mathrm{n} 20$ art 10bis.

48 Antony Taubman, Hannu Wager and Jayashree Watal, A Handbook on the WTO TRIPS Agreement (Cambridge University Press, 2nd ed, 2012) 86. 
that do so. ${ }^{49}$ Therefore, in response to Cuba's claim, Australia's plain packaging regulations do not need to implement Article 22.2(b) if Australia can prove that it implements this article through alternate measures.

\section{Does Australia implement its obligations under Article 22.2(b)?}

Australia can argue that it complies with Article 22.2(b) and 10bis of the Paris Convention by operating a national trade mark register, on which trade mark and GIs right holders can apply to have their marks registered. ${ }^{50} \mathrm{With}$ such registration comes the right to take action against misuse of the registered mark. ${ }^{51}$ Australia can also argue that these obligations are met through a variety of domestic legislation to protect against misleading and confusing conduct.

Australia provides the means to register a GI as a Certified Trade Mark (CTM) under the Trade Marks Act 1995 (Cth) (Trade Marks Act). ${ }^{52}$ CTMs indicate that goods meet standards of quality, composition, or geographical origin and can only be registered if the mark is shown to be distinctive, indicating exclusively the goods or services of the trade mark applicant. ${ }^{53} \mathrm{CTM}$ registration is the same as the registration of standard trade marks and, as a result, CTMs are given similar protection to trade marks in Australia.

Australia also affords protection against misleading and deceptive conduct in several ways. Firstly, under section 126 of the Trade Marks Act, these trade marks and GIs registered as CTMs are protected by prohibiting engagement in misleading or deceptive conduct and through the grant of a proprietary right. ${ }^{54}$ In the case of trade mark infringement the court may grant an injunction on any conditions the court thinks are relevant. Australian courts may also, at the option of the registered CTM owner, grant the owner damages. Secondly, Australia provides protection from consumer deception under section 18 of Australian Consumer Law under the Competition and Consumer Act 2010 (Cth) (Competition and Consumer $A c t) .{ }^{55}$ This section prohibits conduct in trade or commerce that is misleading or deceptive. ${ }^{56}$ The terms 'misleading' and 'deceptive' are not defined in the Act, and the courts have not clarified their meaning. Therefore, the courts look to the overall impression created by the conduct to determine whether it is likely to lead a significant number of people into error or has the tendency to deceive such persons.

\footnotetext{
49 Panel Report, EC - Trademarks and Geographical Indications (Australia) above n 41 [7.751].

50 Trade Marks Act 1995 (Cth).

51 Ibid.

52 Ibid.

53 Sarah Matheson and Des Ryan, Report Q191 in the name of the Australian Group: Relationship between trademarks and geographical indications, (14 June 2006) Association Internationale pour la Protection de la Propriété Intellectuale, www.aippi.org/download/commitees/191/GR191australia.pdf, 4.

54 Trade Marks Act above n 51 s 126.

55 Competition and Consumer Act 2010 (Cth).

56 Ibid s 18.
} 
Furthermore, Australian Consumer Law protects GIs from a third party's false or misleading claims about the country of origin of goods, including displaying symbols usually associated with a particular country on their packaging. ${ }^{57}$ Paragraph 29(1)(a) of the Competition and Consumer Act contains a broad prohibition, which states that:

A person must not, in trade or commerce, in connection with the supply or possible supply of goods or services or in connection with the promotion by any means of the supply or use of goods or services ... make a false or misleading representation that goods are of a particular standard, quality, value, grade, composition, style or model or have had a particular history or a particular previous use..$^{58}$

This protection is extended by paragraph $29(1)(\mathrm{k})$, which prohibits 'false or misleading representation concerning the place of origin of goods. ${ }^{59}$ Breaches of these sections will give rise to civil proceedings and may result in criminal liability under section $151 .{ }^{60}$

Finally, even if a GI is not registered as a CTM under the Trade Marks Act, it is protected in Australia under the common law tort of 'passing off', preventing representations that confuse or deceive the consumer. ${ }^{61}$ To establish passing off, it must be proven that a misrepresentation was made during the course of trade that was intended to damage the business or goodwill of the plaintiff, and caused actual damage. ${ }^{62}$

These legislative measures and common law tort seem sufficient and appropriate to implement Australia's obligations under Article 22.2(b) as they prevent consumer confusion, false allegations, and misleading the public in the course of trade. Even if there was an implied positive 'right to use' a GI under Article 22, Australia's Plain Packaging Act provides the opportunity for Cuban cigar brands to display their brand name, variant names and the country of origin on cigar packaging, thus allowing any textual GI to be displayed. ${ }^{63}$

\section{Cuba's claim under Article 22.2(b)}

Cuba is specifically challenging the Plain Packaging Act with regards to Article 22.2(b), claiming Australia 'does not provide effective protection against acts of unfair competition with respect to Cuban GIs'. ${ }^{64}$

57 Competition and Consumer Act above n 56 ss 29(1)(a) and 29(1)(k); ss 151(a) and (k).

58 Competition and Consumer Act above n 56 s 29(1)(a).

59 Competition and Consumer Act above n 56 s 29(1)(k).

60 Competition and Consumer Act above n 56 ss 151(a) and (k).

61 Erven Warnink v Townend \& Sons Ltd (1979) AC 731 HL 742.

62 Ibid.

63 Tobacco Plain Packaging Act 2011 (Cth).

64 Australia - certain measures concerning trademarks, geographical indications and other plain packaging requirements, applicable to tobacco products and packaging: Request for consultations by Cuba, WTO Doc WT/ DS458/1 (7 May 2013) B. 
Of the 18 Cuban cigar brands registered as appellations of origin on the Lisbon Register, only one is confirmed to be registered as a CTM in Australia: Habanos a GI of Havana, Cuba. ${ }^{65}$ If Cuban cigar GIs, such as Habanos, are registered as CTMs in Australia, they are adequately protected under Australian law through the combination of legislation and common law covering the prohibition against misrepresentation and the grant of proprietary rights. Even if a Cuban cigar brand is not registered as a CTM in Australia, if it has an established name or trade mark, that name cannot be used by another cigar to mislead or confuse consumers as to the origin, characteristics or quality of that cigar, arguably satisfying the protection from unfair competition under 10bis of the Paris Convention and thus 22.2(b). As a result, cigar brands that did not originate in the geographical location will not be able to claim they are Habanos or from Havana, and will be in breach of the Trade Marks Act and the Competition and Consumer Act if they attempt to display that GI.

Cuba will likely argue that, on a theoretical level, Australia's Plain Packaging Act prevents trade marks or GIs from being registered in the future. However, new or unregistered brands still have the opportunity to register their textual GIs as a CTM under the Trade Marks Act, and the opportunity to have that textual GI displayed as the brand name or variant on the cigar packaging. Visual trade marks and GIs (such as the National Warranty Seal of Origin of Cuba) can still be registered as a trade mark or CTM to prevent their use by third parties (which is already inherently prevented due to the plain packaging requirements being applicable to all tobacco products). Australia's Plain Packaging Act is therefore not violating Article 22.2(b) of the TRIPS Agreement.

\section{Article 24.3 and its implementation in Australia}

\section{Obligations under TRIPS Article 24.3}

Article 24.3 creates a positive obligation on members to not diminish the protection for GIs that existed prior to entering the TRIPS Agreement. ${ }^{66}$ Turning to the ordinary meaning of the terms used, ${ }^{67}$ the principal term in Article 24.3 is 'shall not diminish'. This suggests that the article is not an exception; rather, it is a 'standstill clause'. ${ }^{68}$ This is a vague approach to protecting GIs since it assumes a measurement of the strength of protection that is not otherwise found in TRIPS, and is unclear on what the benchmarks for such a measurement would be. Firstly, if the provision relates to a member's system of protection of GIs, it may be

65 Trade Marks Act above n 51.

66 TRIPS Agreement above n 18 art 24.3.

67 Vienna Convention on the Law of Treaties, opened for signature 23 May 1969, 1155 UNTS 332 (entered into force 27 January 1980) art 31.

68 Nuno Pires de Carvalho, The TRIPS Regime of Trademarks and Designs (Kluwer Law International, 1st ed, 2011) 570 . 
difficult to determine what constitutes a diminution in protection. For example, if a member country were to completely reconstitute its legal regime for protecting GIs, with some increases and some decreases in protection, would that constitute diminishing protection? Secondly, it is likely that Australia and Cuba will disagree on the meaning of the term 'protection of GIs'.

This ambiguity was considered by the WTO Panel in EC-Trademarks and Geographical Indications (Australia), ${ }^{69}$ in which the European Community argued the relevant protection being granted to GIs under its 1993 regulations was not only permitted but mandated by Article $24.3 .^{70}$ Due to the regulations existing before the date of entry into the WTO Agreement, the European Community claimed that Article 24.3 prohibited Australia from altering them in a way that would diminish the protection referred to in that article. ${ }^{71}$ The panel reasoned interpreting Article 24.3 as a standstill provision for a system of protection excluded not only the rights that already existed under that system prior to 1 January 1995 but would also exclude rights subsequently granted under that system. ${ }^{72}$ The panel argued that the exclusion 'would grow, rather than diminish, in importance, as an increasing number of GIs were protected under the prior legislation ... [t] he Panel is reluctant to find such an exclusion in the absence of any clear language to that effect' ${ }^{73}$ Cuba acknowledges this in their request for consultations with Australia, stating that 'Australia is diminishing the level of protection afforded to Cuban GIs as compared with the level of protection that existed in Australia prior to 1 January $1995{ }^{74}$ Consequently, we must look to the protection of individual Cuban cigar GIs rather than the GI system of protection in place, prior to 1 January 1995.

\section{Cuba's claim under Article 24.3 and Australia's obligations}

Cuba is bringing action against Australia under Article 24.3 of the TRIPS Agreement, claiming that Australia is diminishing the level of protection afforded to Cuban GIs as compared with the level of protection that existed in Australia prior to 1 January 1995, 'including by restricting the use of Cuban GIs, such as the GI "Habanos", on the retail packaging of large handmade cigar products'. ${ }^{75}$

To prove that Australia is not in violation of Article 24.3, it must be successfully argued that the level of protection afforded to Cuban cigars has not diminished since Australia entered the TRIPS Agreement. As noted earlier, the protection

69 EC-Trademarks and Geographical Indications (Australia) above n 41.

70 Ibid.

71 Ibid.

72 Ibid, [7.635].

73 Ibid, [7.635].

74 Request for consultations by Cuba above $\mathrm{n} 65$ at B (emphasis added).

75 Ibid. 
of Cuban cigar GIs in Australia is currently under the Trade Marks Act, the Competition and Consumer Act, and the common law tort of 'passing off'. No extra protection of these GIs existed prior to 1 January 1995.

Australia may be able to argue that it has in fact strengthened the level of protection afforded to Cuban cigar GIs since 1994, by its amendment of the Trade Practices Act 1974 (Cth) to become the Competition and Consumer Act. ${ }^{76}$ The amendment introduced new prohibitions on false and misleading representations in relation to testimonials and consumer guarantees and additional investigative and enforcement powers for the Australian Competition and Consumer Commission. These changes would have strengthened the level of protection to CTMs under the Trade Marks Act, and further enforced Australia's obligations under TRIPS Article 22.2(a) and (b).

Furthermore, Cuba's argument that plain packaging restricts the use of the GI Habanos is not a particularly strong argument as Habanos is registered as a GI under a textual CTM and not a visual trade mark. ${ }^{77}$ Therefore, given Australia's plain packaging legislation still permits the use of textual GIs so long as such use is consistent with the plain packaging regulations and does not diminish the exclusionary right of GI holders, the GI Habanos is not restricted.

Australia is therefore not in breach of Article 24.3 of the TRIPS Agreement as it has not diminished the protection afforded to Cuban GIs since 1995.

\section{The likely outcomes and implications of the dispute}

\section{The impact of public health policy considerations}

In addition to considering the international trade aspects of the argument, it is necessary for the WTO panel overseeing the dispute to consider public health policy and the WHO's objectives in publishing the FCTC. The Doha Declaration on the TRIPS agreement and public health (Doha Declaration) highlighted the importance of balancing the interests of international trade with the interests of international health, ${ }^{78}$ acknowledging 'that the TRIPS Agreement does not and should not prevent members from taking measures to protect public health'. ${ }^{79}$

\footnotetext{
76 Competition and Consumer Act 2010 (Cth).

77 Intellectual Property in Australia Trademark Database, Habanos Trademark Details, Intellectual Property in Australia (24 August 2012), www.ipaustralia.com.au/applicant/corporacion-habanos-sa/trademarks/1215757/. 78 Declaration on the TRIPS Agreement and Public Health (Doha Declaration), WT/MIN(01)/DEC/2 (20 November 2001, adopted on 14 November 2001) (Ministerial Declaration); Ronald Labonte and Matthew Sanger, 'Glossary on the World Trade Organisation and public health: Part 2' (2006) 60 Journal of Epidemiology and Community Health 738, 740.

79 Doha Declaration above $\mathrm{n}$ at 77 (emphasis added).
} 
Former Director-General of the WTO, Pascal Lamy, acknowledged this duty to work in cooperation, and as a constructive partner, with the WHO. ${ }^{80}$ In his 2009 speech at the World Intellectual Property Organization (WIPO) Conference on Intellectual Property and Public Policy, Lamy stated:

the international intellectual property system cannot operate in isolation from broader public policy questions such as how to meet human needs such as basic health ... [H] ealth policy, the IP system, and the framework for legitimate trade relations are inevitably intertwined and must be managed harmoniously. ${ }^{81}$

Australia's Plain Packaging Act may be argued to be a sound public health measure. Therefore, in response to this increasingly harmonious approach of multilateral cooperation, the WTO may consider Australia's Plain Packaging Act to be necessary to implement the WHO FCTC even if it is found to encumber some intellectual property rights. A decision in favour of Australia will therefore reinforce the legality of pursuing public health objectives over trade mark or GI protection under TRIPS.

\section{The implications if Australia succeeds in its defence}

One of the most significant implications of this dispute, along with the other four WTO disputes regarding Australia's plain packaging, is the impact on other WTO members' tobacco control measures. The impact of plain packaging disputes is particularly significant as Australia is the first country to ever implement a plain packaging measure on tobacco products. The disputes have caused a 'regulatory chill' amongst other members, leading them to refrain from implementing similar legislation in line with the FCTC. The regulatory chill has caused members including the United Kingdom, New Zealand and Canada, which had considered plain packaging, to seemingly back down at the potential threat of international arbitration. ${ }^{82}$ New Zealand's Associate Health Minister stated that their 'government will wait and see what happens with Australia's legal cases, making it a possibility that if necessary, enactment of New Zealand legislation and/or regulations could be delayed pending those outcomes'. ${ }^{83}$

80 Pascal Lamy, 'Strengthening Multilateral Cooperation on IP and Public Health' (Speech delivered to WIPO Conference on Intellectual Property and Public Policy, Geneva, 14 July 2009).

81 Ibid.

82 Kyla Tienhaara, 'Regulatory chill and the threat of arbitration: a view from political science' in Chester Brown and Kate Miles (eds), Evolution in Investment Treaty Law and Arbitration (Cambridge University Press, 2011) 606, 610.

83 Dan Harrison, 'NZ to follow on plain packaging for cigarettes' Sydney Morning Herald (Sydney), 20 February 2013. 


\section{The implications if Cuba succeeds in its claims}

Although Australia has strong legal grounds to argue against Cuba's claims in regards to Article 22.2(b) and 24.3 of the TRIPS Agreement, it is important to consider what measures it would have to remove or implement if Cuba was successful in its claims. If Cuba successfully argued that Australia's Plain Packaging Act was in violation of their cigar GIs, Australia would need to bring its plain packaging measures into conformity with the obligations it has under Articles 22 and 24 of the TRIPS Agreement. ${ }^{84}$ The Dispute Settlement Body rarely exercises its ability to recommend how a member should implement its recommendations and rulings under Article 11 and 19 of the Understanding on Rules and Procedures Governing the Settlement of Disputes, ${ }^{85}$ and so it is likely that, if Cuba succeeded, Australia would determine how to remedy plain packaging to take into account Cuban cigar GI rights. This may be by modifying the Plain Packaging Act to not include fine tobacco products, like handmade cigars, or by allowing the labelling of Cuban cigar boxes 'Hecho en Cuba' (Made in Cuba) or allowing the boxes to be stamped with the creation of the National Warranty Seal of Origin of Cuba.

\section{Conclusion}

Despite Cuba's legal objections to the Plain Packaging Act, claiming that Australia is violating its international obligations under Articles 22.2(b) and 24.3 of the TRIPS Agreement, Australia has a resoundingly strong legal basis to suggest otherwise when domestic law is properly interpreted and taking into account the importance of public health policy under the FCTC. Australia's Plain Packaging Act restricts neither the ability of companies to register their GIs in Australia's trade marks register, nor the right of GI owners to prevent third parties from using their marks without the necessary authorisation. Australia can also argue that GIs are protected by a variety of domestic legislation and this level of protection has strengthened since it entered the TRIPS Agreement in 1995. A timely and successful resolution of these disputes, finding that Australia is not in breach of its international trade obligations, will have a global impact on tobacco control measures and a resoundingly positive impact for public health.

84 Understanding on Rules and Procedures Governing the Settlement of Disputes (DSU), 1869 UNTS 401, art $3(7)$.

85 Ibid art 11 and 19. 


\section{Bibliography}

\section{Articles/books/reports}

Collins, David and Lapsley, Helen, Department of Health and Ageing (Cth), The Costs of Tobacco, Alcohol and Illicit Drug Use to Australian Society (2008).

Davidson, Mark, 'Plain Packaging of Tobacco Products: The new Australian laws and the legal challenges to them' (2013) 9 Anuario Andino de Derechos Intelectuales (Andino Intellectual Rights Yearbook) 195.

Freeman, Becky, Chapman, Simon and Rimmer, Matthew, 'The Case for Plain Packaging of Tobacco Products' (2011) 103 Addiction 580.

Harrison, Dan, 'NZ to follow on plain packaging for cigarettes', Sydney Morning Herald (Sydney), 20 February 2013.

Ibele, Erik, 'The Nature and Function of Geographical Indications in Law' (2009) 10 The Estey Centre Journal of International Law and Trade Policy 36.

Labonte, Ronald and Sanger, Matthew, 'Glossary on the World Trade Organisation and public health: Part 2' (2006) 60 Journal of Epidemiology and Community Health 738.

Martin, Andrew, 'Philip Morris leads plain packs battle in global trade arena', Bloomberg (online), 22 August 2013, www.bloomberg.com/news/2013-0822/philip-morris-leads-plain-packs-battle-in-global-trade-arena.html.

Mitchell, Andrew, 'Australia's Move to the Plain Packaging of Cigarettes and its WTO Compatibility' (2010) 5 Asian Journal of WTO \& International Health Law and Policy, 409.

Mitchell, Andrew and Voon, Tania, Submission No 618 to House Committee on Health and Ageing, Australian Inquiry into Tobacco Plain Packaging, 21 July 2011.

Nuno Pires de Carvalho, The TRIPS Regime of Trademarks and Designs (Kluwer Law International, 1st ed, 2011).

Taubman, Antony, Wager, Hannu and Watal, Jayashree, $A$ Handbook on the WTO TRIPS Agreement (Cambridge University Press, 2nd ed, 2012).

Tienhaara, Kyla,'Regulatory chill and the threat of arbitration: A view from political science' in Chester Brown and Kate Miles (eds), Evolution in Investment Treaty Law and Arbitration (Cambridge University Press, 2011). 
van den Bossche, Peter, The Law and Policy of the World Trade Organization (Cambridge Press, 3rd ed, 2012).

\section{Legislation}

Competition and Consumer Act 2010 (Cth)

Decreto-Ley $N^{\circ} 228$ de las Indicaciones Geográficas 2002 (Cuba)

Competition and Consumer Act 2010 (Cth)

Tobacco Plain Packaging Act 2011 (Cth)

Tobacco Plain Packaging Amendment Regulations 2012 (Cth)

Tobacco Plain Packaging Regulations 2011 (Cth)

Trade Marks Act 1995 (Cth)

\section{Cases}

EC - Trademarks and Geographical Indications (Australia), WTO Doc WT/ DS174/R (15 March 2005)

Erven Warnink v Townend E Sons Ltd (1979) AC 731 HL 74.

\section{Treaties}

Agreement on Trade-Related Aspects of Intellectual Property Rights (TRIPS Agreement), opened for signature 15 April 1994, 869 UNTS 299 (entered into force 1 January 1995).

Declaration on the TRIPS Agreement and Public Health (Doha Declaration), WT/MIN(01)/DEC/2 (20 November 2001, adopted on 14 November 2001) (Ministerial Declaration).

Lisbon Agreement for the Protection of Appellations of Origin and their International Registration (Lisbon Agreement), opened for signature 31 October 1958) 923 UNTS 205 (entered into force 25 September 1966).

Madrid Agreement for the Repression of False or Deceptive Indications of Source (Madrid Agreement), opened for signature 14 April 1891, as revised at Stockholm in 1967, 828 UNTS 389.

Paris Convention for the Protection of Industrial Property (Paris Convention), opened for signature 14 July 1967, 828 UNTS 305 (entered into force 26 April 1970). 
Understanding on Rules and Procedures Governing the Settlement of Disputes (DSU), 1869 UNTS 401.

Vienna Convention on the Law of Treaties, opened for signature 23 May 1969, 1155 UNTS 332 (entered into force 27 January 1980).

World Health Organization Framework Convention on Tobacco Control, opened for signature 16 June 2003, 2302 UNTS 166 (entered into force 27 February 2005).

\section{Other}

Armfield Intellectual Property Management, The question of whether Australia has contravened its obligations under the TRIPS Agreement by enacting the Tobacco Plain Packaging Act 2011 (Cth) is much clearer than many commentators have suggested (1 March 2013) static.squarespace.com/static/50c31438e4b013f4c08abdcb/ t/5296e04de4b08ec721545ab5/1385619533649/Tobacco\%20Plain\%20 Packaging.pdf.

Australia - certain measures concerning trademarks, geographical indications and other plain packaging requirements, applicable to tobacco products and packaging: Request for consultations by Cuba, WTO Doc WT/DS458/1 (7 May 2013).

Chairman's Report - Trade Problems Encountered in Connection with Intellectual Property Rights, TRIPS Doc MTN.GNG/NG11/W/76 (23 July 1990).

Communication from the European Communities - Trade Problems Encountered in Connection with Intellectual Property Rights, TRIPS Doc MTN.GNG/ NG11/W/26 (7 July 1988).

Communication from the European Communities -Trade Problems Encountered in Connection with Intellectual Property Rights, TRIPS Doc MTN.GNG/ NG11/W/68 (29 March 1990).

Communication from the Secretariat - Trade Problems Encountered in Connection with Intellectual Property Rights, TRIPS Doc MTN.GNG/NG11/16 (4 December 1989).

Communication from the Secretariat-Trade Problems Encountered in Connection with Intellectual Property Rights, TRIPS Doc MTN.GNG/NG11/W/12 (11 August 1987).

Communication from the United States - Trade Problems Encountered in Connection with Intellectual Property Rights, TRIPS Doc MTN.GNG/NG11/W/70 (11 May 1990). 
Garrido de la Grana, Adargelio 'The Experience of Cuban Cigar Trademarks and Geographical Indications' (Speech delivered at the WIPO International Symposium on Geographical Indications, Beijing, 27 June 2007).

Intellectual Property in Australia Trademark Database, Habanos Trademark Details, Intellectual Property in Australia (24 August 2012), www.ipaustralia. com.au/applicant/corporacion-habanos-sa/trademarks/1215757/.

Lamy, Pascal, 'Strengthening Multilateral Cooperation on IP and Public Health' (Speech delivered to WIPO Conference on Intellectual Property and Public Policy, Geneva,14 July 2009).

Matheson, Sarah and Ryan, Des, Report Q191 in the name of the Australian Group: Relationship between trademarks and geographical indications, (14 June 2006) Association Internationale pour la Protection de la Propriété Intellectuale, www.aippi.org/download/commitees/191/GR191australia.pdf.

Parliamentary Library, Australia's WTO Plain cigarette packaging case: An update (8 July 2014) Parliament of Australia www.aph.gov.au/About_Parliament/ Parliamentary_Departments/Parliamentary_Library/FlagPost/2014/July/ WTO_plain_cigarette_packaging_case.

World Health Organization, Tobacco Fact Sheet Number 339 (2014) www.who.int/ mediacentre/factsheets/fs339/en/.

World Health Organization, Guidelines for implementation of Article 11 of the WHO Framework Convention on Tobacco Control (Packaging and labelling of tobacco products). Article 46. www.who.int/fctc/guidelines/article_11.pdf?ua=1.

World Intellectual Property Organization (WIPO), Contracting Parties to the Lisbon Agreement (30 July 2013) World Intellectual Property Organization, www.wipo.int/treaties/en/ShowResults.jsp?lang=en\&treaty_id=10.

World Intellectual Property Organization (WIPO), Geographical Indications (21 June 2012) www.wipo.int/geo_indications/en/\#services.

World Intellectual Property Organization (WIPO), Lisbon Express Database, (17 September 2014) World Intellectual Property Organization, www.wipo. int/ipd1/en/search/lisbon/search-struct.jsp. 
This text is taken from The ANU Undergraduate Research Journal, Volume Seven, 2015, edited by Daniel McKay, published 2016 by ANU eView, The Australian National University, Canberra, Australia. 